\title{
E-GOVERNMENT: A COMPARISON OF STRATEGIES IN LOCAL AUTHORITIES IN THE UK AND NORWAY
}

\author{
Vishanth Weerakkody, School of Information Systems and Computing Brunel University, Uxbridge, \\ Middlesex UB8 3PH, UK \\ vishanth.weerakkody@brunel.ac.uk \\ Steve Jones, CONWY County Borough Council, Bodlondeb, Conwy, LL32 8DU, Wales, UK \\ steve.jones@conwy.gov.uk \\ Elisabeth Olsen, School of Information Systems and Computing Brunel University, Uxbridge, \\ Middlesex UB8 3PH, UK \\ olsen.elisabeth@gmail.com
}

\begin{abstract}
In Europe almost all countries have implemented some form of e-government, not to mention the UK and Norway which are now both well into their sixth year of e-government implementation. These six years have seen various strategic plans formulated, implemented and also intermittently postponed in the two countries. Although time may result in the amplification of e-government experience for Norway and the UK, the postponement of implementation deadlines indicates that not only political and social issues, but also strategic and organisational issues need to be addressed when formulating plans for deploying e-government. Using empirical research this paper examines the strategies adopted by the UK and Norway in the context of aligning central and local government plans for implementing e-government services. While technical, political and social issues are considered as key areas to be addressed in any e-government exploitation plan; this paper examines how different perspectives on e-government definition, strategy, awareness and related organisational change influence implementation. The need to align central and local e-government plans, guidelines for local level implementation, user centred solutions, strong leadership and a common understanding of the definition of e-government are highlighted in the paper as some of the key components of good egovernment implementation practice.
\end{abstract}

\section{INTRODUCTION}

The combined influence of the Internet and supporting ICTs have seen commercial enterprises reaching out to people and exploiting business opportunities that would have previously not been possible. Internet enabled e-business has also contributed to a significant increase in the speed and ease of business transactions making not only competition intense between organisations, but also requiring companies to integrate new and faster systems and adjust to new technology to meet the needs of customers (Deitel et al., 2001; Weerakkody and Choudrie, 2005). Although commercial enterprises and governments had little in common prior to the e-commerce era, government and industry e-commerce agendas have become more closely linked in recent times (OECD, 1997). Conversely more people are now less tolerant of poor, impersonal service in the public sector as they become aware of the power of the web and experience good service in the private sector (Holmes, 2001; Silcock, 2001; Stamoulis et al., 2001). Therefore, it is in every government's interest to make their public services more efficient and available in order to gain citizens' trust, which has often eluded many governments and political leaders in modern society. However, for e-government implementation to be widespread and successful, exemplary strategies and practices need to be identified in addition to establishing and prioritising processes to be e-enabled. Furthermore, every e- 
government programme needs to have a clear idea of the proposed benefits to citizens, what challenges need to be overcome and the level of institutional change that needs to take place for it to be successful in a given context (Raffat, 2003; Hazlett, et al., 2003; Silcocks, 2001).

Not surprisingly, with the increasing adoption of e-government, academics, consultants and solutions providers (vendors) all want to pronounce their expert opinions. Like with many preceding organisational improvement concepts (such as business process reengineering and e-business) the varying definitions suggested for e-government does not help. Holmes (2001, p2) defines egovernment as "the use of technology, in particular the Internet, to deliver public services in a much more convenient, customer-oriented, cost-effective, and altogether different and better way". Raffat (2003, p1) states that "e-government initiatives are complex change efforts intended to use new and emerging technologies to support a transformation in the operation and effectiveness of government". The definition that the authors prefer however is the one offered by the Information Society of the European Commission. They define e-government as "the use of information and communication technology in public administrations combined with organisational change and new skills in order to improve public services and democratic processes and strengthen support to public policies” (Europe's Information Society, 2005). In a narrower context and for this paper, the authors accept the notion that e-government is defined as the use of the ICT to procedures and outcomes of central and local government and their administrative structures (Chadwick and May, 2003; Wimmer, 2002). Although all the above definitions mention common words such as technology and change, yet the implementation of e-government in different countries often implies different objectives and levels of transformation to their public services (Navarra and Cornford, 2003). While plans in Europe focus on speeding up the development of public e-services EU-wide (Cuddy, 2003), in the UK plans are focused on e-enabling all key public services by the end of 2005 (Office of the Deputy Prime Minister, ODPM, 2005).

It is outside the scope of this paper to investigate to what extent the UK plans have been implemented. However, current research suggests that there has been mixed success and not all Authorities have achieved the target (SOCITM, 2006). Irrespective of these different plans and successes however, in order to find good practice in implementation of e-government it is important to look at different countries and examine their strategies and solutions to identify what is working and what is not. Also, it is imperative to understand the benefits and the various challenges faced in an e-government context as well as the organisational change aspects of e-government from a theoretical perspective before embarking on practical implementation. The rationale for this research lies in the reasoning that identifying good practices as well as problems encountered during the process of e-government implementation in different countries, in particular within the same geographic region may encourage knowledge sharing and better implementation practices for individual countries (Lillrank, 1995). This is particularly relevant for many of the European nations who are lagging behind their own individual country deadlines for e-government implementation and more importantly trailing parts of the North American and Asian region in e-readiness (Accenture, 2003; Accenture, 2005). Using this reasoning, we will examine two European nations, the UK and Norway with a view of identifying their a) egovernment strategies, b) good practice implementation scenarios and c) what challenges they face and how they tackle these. The basis for selecting the UK and Norway was influenced by the fact that these two countries have an interesting and different history in the Accenture e-government rankings and the two countries are also significantly dissimilar in size. In the Accenture rankings since 2001, the UK has been steady (around $6-9$ position) while Norway initially was in a leading position before it dropped down and then climbed up to the top five again (Accenture, 2001; Accenture 2003; Accenture, 2005). There are also several government papers that set out the vision including the Cabinet Office (1999; 2000) and ODPM (2003). Heeks (1999) also sets out the e-government challenge to the public sector community.

This paper is structured as follows. The next section identifies the challenges facing e-government and the impact of effective strategy formulation and organisational change management on e-government. 
This is followed in section 3 by a summary of the approach and methods used to carry out the research discussed in this paper. Section 4 outlines the e-government strategies and implementation plans in the UK and Norway and presents the results of the empirical study of local councils in the two countries that capture the local perspective of e-government definition, strategy, challenges, awareness and related organisational change. A discussion follows in section 5 with a comparative analysis of the strengths and weaknesses of the two e-government initiatives using a SWOT analysis (Mintzberg, 1994). The paper concludes by outlining the main research findings and some areas for future research.

\section{FORMULATING EFFECTIVE STRATEGIES FOR E-GOVERNMENT}

Like any project, for e-government to succeed, a good strategy and realistic goals need to be set and supported by well thought out project plans. There is a dual role for the Cabinet Office and OPDM is setting the UK e-government agenda for local government. There are several UK government papers setting out the vision, such as the Cabinet Office (1999; 2000) and ODPM (2003). In essence, strategic planning involves defining the scope and direction of the organisation over the long term taking into account the influence of available resources and environmental forces in a given context (Graetz et al., 2002; Mintzberg, 1994). However, similar to e-business in the 1990's, e-government is currently embryonic and can be viewed as a concept operating in a dynamic and changing environment. Therefore, it is yet unknown whether a more rigid, comprehensive approach to e-government strategic planning (Sambamurthy et al., 1994; Earl, 1993; Galliers, 1991; McFarlan 1971) or a more flexible, incremental approach (Sambamurthy et al., 1994; Earl, 1993) is suitable. While advocates of comprehensive planning (Mintzberg, 1994) suggest that this approach will succeed in a turbulent environment such as e-government, critics such as Johnson and Scholes (1999) argue that a more flexible, incremental approach is suited for such environments.

When examining the aforementioned reasoning in the context of e-government, it can be argued that in a comprehensive or rational approach to strategy formulation the rigid formal planning based on predefined criteria can often result in a top down planning process (Sambamurthy et al., 1994) that is remote from actual reality (Earl, 1993). In contrast, it can be said that a more incremental approach to planning is better suitable to facilitate the new and changing portfolio of challenges and needs that a concept such as e-government may present. Irrespective of the planning approaches that different governments may use however, government institutions are different from private businesses and therefore can not replicate e-business plans from the private sector and implement them. Rather, governments have to make their own strategy, establish their own visions and consider all possible ways of delivering quality, cost-effective public services in ways that citizens and businesses want to receive them (Holmes, 2001).

Considering the above arguments, establishing the meaning of e-government therefore is the essential first step that must be taken in creating an overall strategy for any given environment (Information Service Division, 2002). According to Hunter and Jupp (2001), a true Internet strategy must examine all aspects of the business model, interactions with customers and stakeholders, and should identify those areas where more value can be created for all stakeholders, by moving processes and interactions online. The plan of action for e-government should, therefore according to Lowery (unknown, p. 3) include the following: a clear definition of e-government that covers key areas to be addressed and identification of all customers; a vision that is easily understood and succinctly expresses the concept of and plans for e-government; specific goals and objectives that can be monitored and measured; and identification of policies necessary to support e-government. Holmes (2001) argues that from the various e-government strategies and actions there are five underlining principles emerging: put information and services online and do everything online; ensure easy and universal access to online information and services; skill government employees to be knowledge workers; work in partnership 
to make it happen; and remove barriers and lead by example. Heeks (1999) highlights the challenge of e-government to the public sector community.

Given the above arguments, examining two different countries (The UK and Norway) and their strategy for e-government therefore is timely and is a suitable way of identifying good practice scenarios.

\subsection{The UK E-government Vision: Aligning Central and Local Strategies}

To reach the e-government vision in the UK, the government has developed a cohesive strategy with a clearly articulated action plan that leverages the resources of the private sector. This is backed by a strong leadership structure to ensure communication to citizens and benchmarks for measuring progress (Accenture, 2003). The key player in promoting e-government initiatives within local councils in the UK is the labour government. The government has four guiding principles for egovernment: building services around the citizens needs; making government and services more accessible; social inclusion; and making better use of information (www.computerweekly.com). The UK has always been conscious that e-government is a means to help drive the local policy objectives of mainstream services, release efficiency gains and achieve tangible improvements in terms of shared priorities agreed between central and local government (ODPM, 2005).

The formation of the office of the e-envoy following the Prime Minister's announcement of the Government's commitment to delivering 100 percent of public services online by 2008 was the key to the UK's e-government program. This target of 2008 was subsequently revised to 2005, to quicken the pace of deployment and making the timetable very ambitious. However, in 2005 the ODPM announced it would extend its support programme from 2005 to 2008. This was not a change of target back to 2008, as many local councils were on course to deliver the target. Rather, the purpose of the support programme was to assist any stragglers.

In November 2002 the National Strategy was published and was aimed at creating a common framework where local strategies can be planned with confidence. The framework also described what needed to be put in place nationally to help this happen. Common priorities for developments in technology and joined up services that would reduce the costs of councils were also identified (ODPM, 2003). In transforming services, local government will be e-business oriented, more accessible, convenient, responsive and cost-effective (ODPM, 2002). Consequently, the UK initiated broad changes to its e-government program in 2004. Along with significant increases in expenditure on IT and progress on a number of high profile programs, a new vision for ICT has been developed, spearheaded through the reformation of the office of the e-envoy into the e-government Unit (eGU). "The new role of the eGU is focused on ensuring that IT supports the business transformation of government itself so that it can provide better, more efficient public services” (Accenture, 2005 p 94). Each government agency is responsible to define its own IT strategy that will join up with other services to support the eGU's plans (Accenture, 2005).

The picture in Wales was different to that of the rest of the UK. In Wales, the targets were less ambitious, with the Welsh Assembly Government stating that the public sector had to develop Implementing Electronic Government Statements, which set out each Authority's vision by July 2003. The Welsh Assembly did not require Welsh Councils to implement all services online by 2005, as was the situation in the rest of the UK. Rather, the Assembly required Councils to develop e-government services based on local context and citizen needs (National Assembly for Wales, 2002).

\subsection{E-Government in Norway: Automating and E-Enabling Public Services}


The Norwegian Government first outlined its e-government initiative in a policy document titled 'Electronic Government' in January 1999. The objective was to increase the extent of which businesses and citizens can deal with the government online. This policy formed the basis of the Easier Norway initiative, now renamed eNorway. The goals of eNorway are: access to new technology for all citizens; increased knowledge and confidence among citizens so they can use ICT according to their individual needs; stimulation of democratic involvement; and efficient use of resources (NMLGA, 2001; Accenture, 2003; Accenture, 2001). A key component of eNorway therefore is a 24/7 public administration strategy which is aimed at delivering tailored services to meet users' demands in a well coordinated and user oriented manner (Norwegian Ministry of Labour and Government Administration, NMLGA, 2001).

A more in-depth Norwegian action plan for e-government was published by the NMLGA in 2003, and was called 'strategy for ICT in the public sector: strategy 2003-2005'. This plan details more specific e-government targets and how to meet them and covers a broad range of e-government necessities, for example drawing up requirements for electronic signatures, stimulating the development of broadband, removing obstacles to electronic reporting, and knowledge management to deal with the identification, development and dissemination of knowledge critical for government agencies (Accenture, 2004; Norwegian Ministry of Modernisation, 2005; NMLGA, 2003). By creating a national ICT infrastructure and providing framework conditions, the goal of the strategy is to support good local solutions. Various sectors and agencies have to carry out the enhancement of userorientation, efficiency and simplification in ways that result in gains for both the public administration as a whole and for its users (NMLGA, 2003; Norwegian Ministry of Trade and Industry, 2004). The Norwegian Ministry of Modernisation was created subsequently in June 2004 and took over the responsibilities for coordinating Norway's IT policy. A new eNorway plan, eNorway 2009, was introduced in June 2005 and is focusing on three areas: the individual in the digital Norway; innovation and growth in Norwegian business and industry; and a coordinated and user-adapted public sector (Norwegian Ministry of Modernisation, 2005; Accenture, 2005).

\section{THE RESEARCH METHOD}

The research aim and objectives of this paper are achieved using primary and secondary research. The secondary research consisted of information gathered from both academic and non-academic literature, while the primary research involved the undertaking of an empirical study. A quantitative research approach (using questionnaires) was used for the empirical study to gather as much information as possible in a short period of time (Cornford and Smithson, 1996). Questionnaires were selected as the preferred data collection method as they are relatively inexpensive and less time consuming to administer to a larger sample (local councils in this case) and have the ability to provide both quantitative and qualitative data (ibid). As expected, the research process that was applied went through different stages, which consisted of: outlining the research question/problem; literature review; choosing a research plan; executing the plan; data collection; analysing data; and reporting the findings (Gorman and Clayton, 2005; Creswell, 2003; Myers, 1997; Boulton and Hammersley, 1996).

In questionnaires information is gathered by asking people directly about the points concerned with the research (Denscombe, 2003; Bordens and Abbott, 2002; Myers and Avison, 2002; Harlambos and Holborn, 2004) and finding out what a selected group of participants do, think or feel about a certain topic or subject (Hussey and Hussey, 1997). As suggested by Synodinos (2003) a number of issues were considered when designing the questionnaire for this research. Firstly, a simple structure was followed and where technical phrases were used a brief explanation was provided in order to make sure that the questionnaire would be filled out correctly. Secondly, both open-ended and closed-ended questions were posed based on their response format; the questionnaire consisted of around $75 \%$ tick boxes so it was quick to fill out for the respondents. Thirdly, a cover letter was attached as an introduction in order to explain who the researchers represent, how/why the respondent was selected, 
and the importance of the respondent's answers to the research, while the main body contained the topical questions ordered logically and in a manner non-threatening to respondents (Synodinos, 2003). The questionnaire consisted of 21 questions which covered topics including e-government strategy, focus, awareness, implementation challenges, services currently offered, level of maturity, the impact and level of ICT enabled change, and good practice.

The questionnaires were sent to between one to three employees in 40 different councils in Norway. People who worked in IT and other senior and middle management level employees involved in egovernment implementation were targeted. Names of these individuals were identified through websites and by telephoning the relevant councils. From the 40 that were sent 16 completed questionnaires were received from Norway. The researchers tried to cover as many councils as possible by sending the questionnaires to councils in every part of Norway and the responses received covered a good geographic proportion. In the UK the questionnaires were sent to 25 councils and 12 responses were received. Like Norway, the survey was sent to IT and non IT staff involved in egovernment. Relevant councils were identified through council websites and by telephoning the different councils and the questionnaires were distributed geographically. All the questionnaires that were completed and returned in the UK were usable. While the nature of this research did not permit the administering of a pilot survey (Cornford and Smithson, 1996), feedback from two colleagues who are involved in e-government research was used to ensure that inappropriate or confusing questions were not posed (Walliman, 2001).

Names of councils have not been identified in the paper for confidential reasons. Numeric codes were allocated to the Norwegian councils together with the letters NR (1NR -16NR). Similarly, the UK councils are identified as $1 \mathrm{UK}-12 \mathrm{UK}$. An overview of the councils is provided in table 1 .

\begin{tabular}{|c|c|c|c|c|c|c|}
\hline & \multicolumn{3}{|c|}{ Norway } & \multicolumn{3}{|c|}{ The UK } \\
\hline Council & $\mathrm{Km}^{2}$ & Citizens & Geo & $\mathrm{Km}^{2}$ & Citizens & Geo \\
\hline NR/UK 1 & 21000 & 1400 & North & 51 & 223700 & East \\
\hline NR/UK 2 & 2558 & 61896 & North & 80 & 241000 & South \\
\hline NR/UK 3 & 110 & 4600 & West & 112 & 439473 & Middle \\
\hline NR/UK 4 & 362 & 23959 & West & 378 & 224600 & West \\
\hline NR/UK 5 & 70 & 24000 & East & 42 & 190400 & South \\
\hline NR/UK 6 & 921 & 41760 & North & 50 & 221100 & Middle \\
\hline NR/UK 7 & 98 & 40295 & West & 117 & 43000 & North \\
\hline NR/UK 8 & 456 & 18101 & East & 112 & 266600 & North \\
\hline NR/UK 9 & 342 & 151408 & Middle & 22 & 217000 & East \\
\hline NR/UK 10 & 276 & 73977 & South & 56 & 300948 & Middle \\
\hline NR/UK 11 & 77 & 42150 & East & 27 & 266169 & East \\
\hline NR/UK 12 & 195 & 5259 & East & 274 & 977087 & Middle \\
\hline NR 13 & 191,5 & 7050 & South & & & \\
\hline NR 14 & 70 & 113991 & South & & & \\
\hline NR 15 & 477 & 25075 & Middle & & & \\
\hline NR 16 & 752 & 1909 & Middle & & & \\
\hline
\end{tabular}

Table 1: The Size, Geographic Location and Population of the Councils Surveyed

\section{A COMPARISON OF E-GOVERNMENT IN NORWAY AND THE UK}

From the evidence presented thus far it is clear that the UK and Norway both consider e-government as a national priority. However, as expected their focus, strategies and implementation plans differ from each other. What is common though is that in their e-government implementation, both the UK and Norway are focusing on building services around the citizens' needs and making government and 
services more accessible with the use of ICT. While the UK strategy has stronger guidelines at local level, the Norwegian strategy is focusing on solving the challenges of e-government centrally. Each council in Norway has to make their own strategy for user orientation of services, efficiency and utilisation of ICT although the central strategy outlines the direction. In comparison to the UK, Norway has not had strong leadership to push the implementation of e-government forcefully. However, with forming of the Norwegian Ministry of Modernisation in 2004, there has been a stronger focus on implementation recently. In contrast, the UK government has had a unit for ICT and e-government since 1999. From the information obtained from various policy statements and web sites (ODPM, 2005; ODPM, 2002; NMLGA, 2003) and reports (Accenture, 2005) the main features that characterise the e-government initiatives in the UK and Norway can be summarised in Table 2 offering a high level comparison of the two countries' e-government efforts.

\begin{tabular}{|c|c|c|}
\hline & The UK & Norway \\
\hline Started & 1997 & 1999 \\
\hline vision & $\begin{array}{l}\text { A modern, efficient government which } \\
\text { meets the needs of citizens and } \\
\text { businesses and utilises the benefits of } \\
\text { latest developments in e-business. }\end{array}$ & $\begin{array}{l}\text { A public sector with active participation } \\
\text { in democratic arenas, with equal, } \\
\text { individually tailored high quality services, } \\
\text { efficient use of resources and in which } \\
\text { efficient public services will represent a } \\
\text { competitive advantage for industry. }\end{array}$ \\
\hline focus & $\begin{array}{l}\text { Government portals and links to private } \\
\text { sectors to be implemented and to have } \\
\text { all government services accessible } \\
\text { electronically by the end of 2005; focus } \\
\text { on improving existing services and } \\
\text { redesigning government structures. }\end{array}$ & $\begin{array}{l}\text { User accessibility, stimulation of } \\
\text { democratic involvement and efficient use } \\
\text { of resources; make the everyday life } \\
\text { easier for the citizens and secure the } \\
\text { social welfare system; utilizing and } \\
\text { realizing the opportunities of technology. }\end{array}$ \\
\hline \multicolumn{3}{|c|}{ Local e-government } \\
\hline implementation & $\begin{array}{l}\text { The office of the deputy prime minister } \\
\text { has developed a common model to help } \\
\text { local councils to understand the picture } \\
\text { of the local e-government strategy, } \\
\text { analyse the current position and } \\
\text { implement the strategies. }\end{array}$ & $\begin{array}{l}\text { The government will support good local } \\
\text { solutions, but various sectors and } \\
\text { agencies have to carry out the } \\
\text { enhancement of user-orientation, } \\
\text { efficiency and simplification of services } \\
\text { in ways that will result in gains for the } \\
\text { public administration as well as the user } \\
\text { community / citizens. }\end{array}$ \\
\hline changes & $\begin{array}{l}\text { The office of e-Envoy was established } \\
\text { in } 1999 \text { to encourage the UK } \\
\text { population as a whole to get on-line and } \\
\text { working with departments to make all } \\
\text { government services available } \\
\text { electronically by the end of } 2008 \\
\text { (subsequently revised to 2005). The e- } \\
\text { government Unit was established in } \\
2004 \text { and focuses on government as a } \\
\text { service provider and ensuring the } \\
\text { public sector make best use of } \\
\text { technology. }\end{array}$ & $\begin{array}{l}\text { The Norwegian Ministry of } \\
\text { Modernisation was established in } 2004 . \\
\text { This ministry focus on making the daily } \\
\text { life easier for the population as a whole } \\
\text { and ensure security for future prosperity } \\
\text { and welfare. They have been responsible } \\
\text { for started many e-government projects. }\end{array}$ \\
\hline
\end{tabular}

Table 2: Comparing and contrasting e-government in the UK and Norway

The empirical information gathered from the sixteen questionnaires that were received from Norway and twelve received from the UK has been divided into key themes (Boulton and Hammersley, 1996): 
e-government definition; strategy; challenges; awareness; and organisational change, and are in the following sections.

\subsection{The Councils’ Perspective of the Definition of E-government}

From the responses received, it was evident that all 12 local councils in the UK and 16 Norway councils have implemented some form of e-government. However, the understanding of e-government differed between the councils and between the two nations in general. Table 3 shows an overview of different definitions that were suggested by the respondents in Norway and the UK.

\begin{tabular}{|c|l|l|l|}
\hline Council & \multicolumn{1}{|c|}{ Norway } & Council & \multicolumn{1}{|c|}{ The UK } \\
\hline NR1 & $\begin{array}{l}\text { ”Action and implementation of } \\
\text { electronic council services”. }\end{array}$ & UK1 & $\begin{array}{l}\text { "Opening up access to council services using new } \\
\text { electronic channels". }\end{array}$ \\
\hline NR2 & $\begin{array}{l}\text { "Make public services accessible } \\
\text { through the Internet”. }\end{array}$ & UK2 & $\begin{array}{l}\text { "To allow our customers to access our services and } \\
\text { information 24/7. To allow our customers to interact } \\
\text { with us 24/7 (i.e. pay, apply and report)" }\end{array}$ \\
\hline NR3 & $\begin{array}{l}\text { "Information and application } \\
\text { collection, and status of } \\
\text { applications accessible through } \\
\text { electronic medium”. }\end{array}$ & $\begin{array}{l}\text { UK3 } \\
\text { "Electronic commerce both in } \\
\text { and within the public sector". }\end{array}$ & $\begin{array}{l}\text { "Improving customer access to council services using } \\
\text { the latest cross-cutting technologies (IT enabled } \\
\text { business strategy for government and wider public } \\
\text { sector)". }\end{array}$ \\
\hline NR4 & $\begin{array}{l}\text { "Multi channel customer access involving CRM and } \\
\text { integrated back office systems, supported by change } \\
\text { management and reengineering of processes". }\end{array}$ \\
\hline
\end{tabular}

Table 3: The Employee Perspective of E-Government in the UK and Norway

\subsection{Local Government Perspective of E-Government Strategy}

An important part of the questionnaire was focused on identifying the councils' perspective of egovernment strategy. In Norway, only 4 councils out of 16 thought that national strategy in highly important and the rest viewed it as important (2 councils), quite important (4 councils) or slightly important (6 councils). In comparison, in the UK, 3 councils stated that it was slightly important and 9 stated it was highly important. Of the 16 councils in Norway 8 have a local strategy in comparison to 10 out of the 12 respondents in the UK. On questions about the importance of a local strategy, just 8 councils from Norway that had a local strategy answered; 4 thought it had an importance, 2 felt it was quite important, while 2 stated it was very important. In comparison, all 12 respondents from the UK stated it had high importance. The respondents were also asked if they had any suggestions to improve the national and local strategy. In Norway 8 out of the 16 chose not to answer this question while all 12 respondents from the UK answered it. Some of the suggestions for improving national and local level e-government strategy are shown in table 4.

\begin{tabular}{|c|l|l|l|}
\hline Council & \multicolumn{1}{|c|}{ Norway } & Council & \multicolumn{1}{c|}{ The UK } \\
\hline NR2 & $\begin{array}{l}\text { "Action from central } \\
\text { government is necessary, and } \\
\text { has recently been taken". }\end{array}$ & UK2 & $\begin{array}{l}\text { "We need a forward looking eGov strategy for post } \\
\text { December 2005”. }\end{array}$ \\
\hline NR4 & $\begin{array}{l}\text { "Coordinate internal strategy, } \\
\text { more consistent methodology for } \\
\text { the evaluation of implemented } \\
\text { systems and examining the level } \\
\text { of user satisfaction”. }\end{array}$ & $\begin{array}{l}\text { "Guidance has not always been clear on how central } \\
\text { government would prefer local authorities to } \\
\text { prioritise e-government delivery. Web accessibility } \\
\text { rules can often seem like a barrier to providing the } \\
\text { level of functionality the targets are driving for. } \\
\text { Again, guidance has been minimal". }\end{array}$ \\
\hline
\end{tabular}

Table 4: The Councils’ Perspective on How to Improve National Strategy 


\subsection{The Councils' Perspective of the E-Government Challenges}

The key e-government challenges identified in the literature were further explored through the questionnaire. These were awareness, security, accessibility, trust, privacy, digital divide and understanding the citizens' needs. Figure 1 summarizes how important the Norwegian councils think the above challenges are, while figure 2 summarizes their importance as seen by the UK councils. The levels of IT support and IT resources available for e-government in the two countries were also measured in the questionnaire. As shown in figure 3, many of the councils in the UK suggested that they had moderate IT support and resources while the responses in Norway varied between moderate to adequate IT resources and between little to moderate IT support.

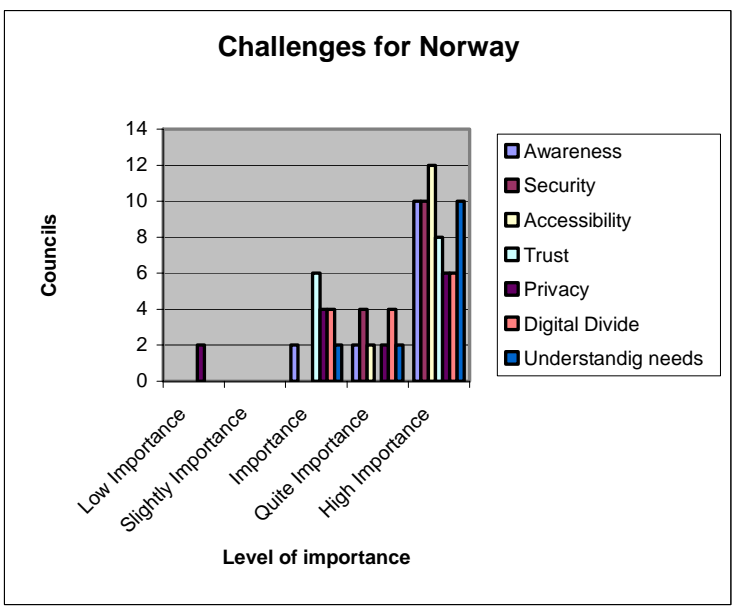

Figure 1: The Councils' Perspective of the Egovernment Challenges in Norway

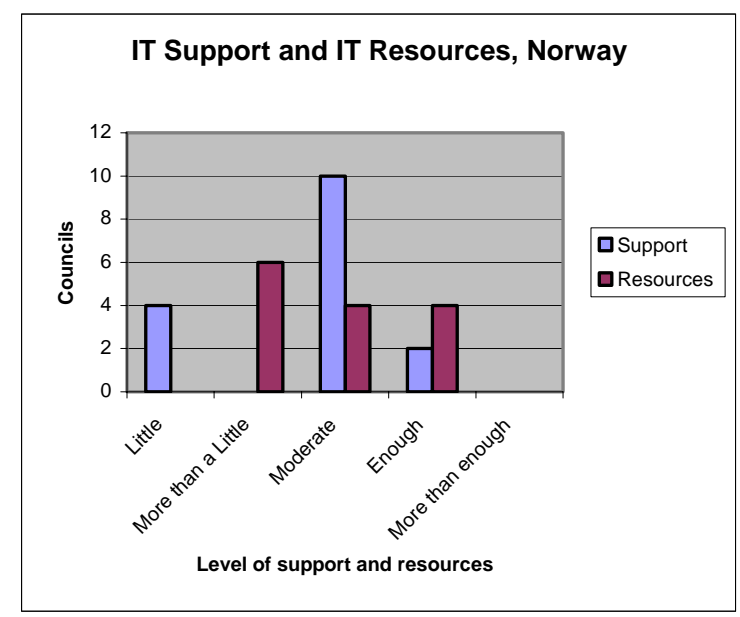

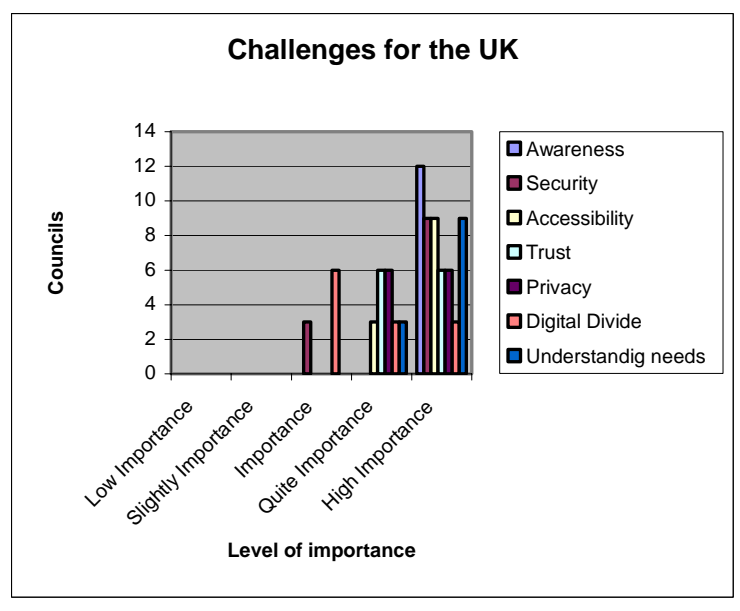

Figure 2: The Councils' Perspective of the Egovernment Challenges in UK

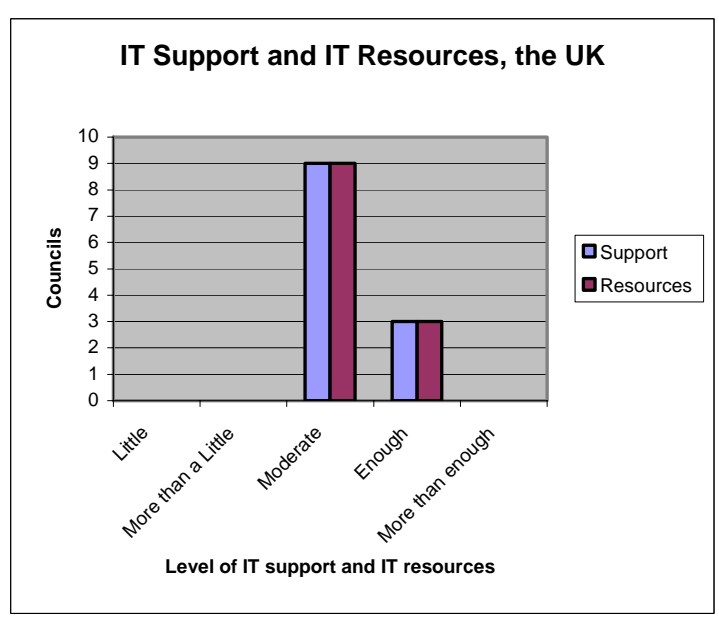

Figure 3: Level of IT Support and IT Resources in Norway and the UK

\subsection{E-Government Awareness}

Awareness is a key issue in e-government and was noted as a high important challenge for most of the councils that participated in the survey. In order to find out about the awareness in the different 
councils other questions have also been asked to get an understanding of the bigger picture. It was revealed that 14 of the 16 councils in Norway offer $20 \%$ of their services online, while the last two offer $60 \%$. The most used services in Norway are applications for jobs, accessing local government information, local news and child care related information and applications. In the UK, jobs, events, libraries, planning, information and payment were mentioned. On question about how many of the councils' citizens were aware of the online services they offered, 6 councils in Norway suggested 20 $\%$, 2 suggested $40 \%$ and 8 suggested that $60 \%$ of the citizens were aware of e-government. In comparison, in the UK, 6 councils suggested that $20 \%$ of their citizens were aware of their services on-line while 6 suggested $60 \%$ were aware. Although the councils in both Norway and the UK have their own websites, they have different ways of making citizens aware of the services they offer online. In Norway government information brochures was most used, but also commercials in newspapers, information through the council's own web site, face-to-face information and notice boards were mentioned. In the UK the most used medium were notice board and distributed information papers. Newsletters, commercials in newspapers and on TV, face-to-face information and radio were also mentioned.

\subsection{The Impact of Organisational Change in E-Government}

The councils' perspective of organisational change in respect to e-government was interesting. Out of the 16 responses from Norway, 8 mentioned that the initiative had changed the way they are working. In contrast all 12 from the UK stated that their way of working had changed. Table 5 quotes some of the changes that have taken place.

\begin{tabular}{|c|c|c|c|}
\hline Council & Norway & Council & The UK \\
\hline NR1 & $\begin{array}{l}\text { "You become more focused when working } \\
\text { with a client electronically. The relationship } \\
\text { becomes more organised and less personal". }\end{array}$ & UK1 & $\begin{array}{l}\text { "Focus is on the transformation of services } \\
\text { using enabling technologies to achieve } \\
\text { improvements in service delivery". }\end{array}$ \\
\hline $\mathrm{NR}^{3}$ & $\begin{array}{l}\text { "Some of the internal communication has } \\
\text { become better and more efficient with the use } \\
\text { of e-mail. Search possibilities have also } \\
\text { become much better". }\end{array}$ & UK & $\begin{array}{l}\text { "Much greater focus on electronic service } \\
\text { delivery over the last } 3 \text { years. We are } \\
\text { reengineering services in line with the Key } \\
\text { Priority targets". }\end{array}$ \\
\hline
\end{tabular}

Table 5: Comments on How E-Government Has Changed the Way of Working in Councils

When it came to the overall focus of organisational change for each council, there were differences in the answers which ranged from rationalisation of procedures to automation and paradigm shift in Norway. In contrast the answers were more straightforward in the UK where the focus was on reengineering, paradigm shift and automation.

\section{DISCUSSION}

This research has shown that although the high level aims and objectives of e-government are the same for many countries, the implementation strategies, plans and focus vary from country to country. It was found that while councils in Norway focused more on local government modernisation, and the automation and rationalisation of procedures in an e-government definition, councils in the UK focused on reengineering processes and change management. From a tactical perspective, both national and local strategy was seen to be more important in the UK than what the councils in Norway suggested. Accessibility was the most important challenge ranged by the Norwegian councils while the UK councils had awareness as their number one challenge. From an organisational change 
perspective, half of the respondents from Norway and all the respondents from the UK mentioned that e-government had changed their way of working.

When it came to e-government strategy, it was clear that UK has more central guidelines for local egovernment. This is shown in the results from the questionnaire where almost every council that participated had a local strategy while only around half of the councils that answered from Norway had such strategies. The UK has a larger amount of services available online compared to Norway, however the councils in Norway was of the opinion that their citizens are more aware of the services than the councils in the UK.

When comparing the empirical research findings to the literature there is a similar focus and level of importance in the different e-government challenges from both a theoretical and practical perspective. However, strategy and organisational change are two topics that are seen to be more important theoretically than what was actually found in practice. With regards to good practice, this research indicates that e-government should be defined with cues such as customer oriented local government, service delivery online, change of work processes and the use of ICT to maximize service efficiency and cost savings. Local councils have come further in the UK than in Norway and this is attributed to two reasons: a) the UK has a local strategy promoted by the government which the local councils are guided to follow and b) the UK has had strong leadership from the start of the e-government initiative in 1999.

From the perspective of strategy formulation, it is evident that the UK e-government initiative is influenced by a comprehensive-centralised-top down approach to planning and implementation (Mintzberg, 1994), whereas the Norwegian e-government initiative follows a more decentralisedincremental approach to planning (Johnson and Scholes, 1999). Given the limited scope of the research discussed in this paper however, it is futile to suggest which of these approaches are more suitable for e-government. The fact that different sources have identified both the UK and Norway in various positions in the world e-government rankings from 2002 to 2005 does not help either ${ }^{1}$. Nonetheless, it is fair to conclude here that whichever strategy and implementation plans individual governments decide to pursue for their e-government initiatives, they need to be driven by the needs of local government and more importantly the citizens' (www.kablenet.com).

A practical approach to performing a comparative analysis of e-government in the two countries is through a SWOT analysis of the strategies, plans and challenges faced by the two countries in their egovernment efforts. A SWOT analysis is a simple but highly effective way of evaluating a business and the strategies deployed by organisations to conduct business in a given market environment (Mintzberg, 1994; Botton and McManus, 1995; Jackson et al., 2002; Valentin, 2001). The four initials in SWOT stand for strengths, weaknesses, opportunities and threats and it is typically used to undertake a structured analysis that aims to gather findings, which can contribute to the formulation of a strategy (Mintzberg, 1994). As outlined in figure 4 the SWOT analysis in this context however summarises and provides a comparative snapshot of the key research findings in the context of egovernment in Norway and the UK.

\footnotetext{
1 The UK was classified as $6^{\text {th }}$ in 2002 and fell to $12^{\text {th }}$ place in 2005 in the world e-government rankings according to Accenture (2002; 2005) while Waseda University (2006) place the UK in 9th position and Norway in $13^{\text {th }}$ according to their research.
} 


\section{STRENGTHS}

- Strong central and local e-government strategy;

- LG plans aligned well with CG strategy;

- Strong leadership, focus and commitment at both CG and LG government levels;

- Availability of guidelines for local level egovernment implementation projects;

- Strong emphasis on process improvement and change;

\section{WEAKNESSES}

- Lack of e-government awareness;

- E-service availability varies from council to council (some as low as $20 \%$ );

- Lack of common understanding of the definition and focus of e-government;

- E-government strategies and plans are less user centred and more organisational focused;

\section{OPPORTUNITIES}

UK

- Good practices beginning to emerge from local e-government implementation projects which can be shared with less successful councils;

- Opportunities to learn and replicate business models from successful e-business firms;

- The emergence of new, cost effective solutions for information exchange, and process and IT integration for web based service provisioning (such as XML, SAO and Web Services);

\section{THREATS}

- Low level of Internet access/usage;

- Too ambitious deadlines may result in less robust, quick fix solutions;

- Ensuring the security of user data and transactions in e-government not seen as a high priority challenge at LG level;

- No indication of renewed / better plans for marketing e-government to raise the current low level of awareness among citizens:
STRENGTHS NORWAY

- User centred approach to transforming / epublic services;

- E-government used as a means of promoting democratic involvement and efficient use of resources;

- Emphasis on providing tailored and user oriented services to meet citizens' demands;

- High level of e-government awareness among citizens;

WEAKNESSES NORWAY

- Lack of alignment between CG and LG strategy where the latter is seen as less important;

- Low levels of online (e-government) service availability;

- Limited IT support and resource availability for local e-government implementation;

- Lack of common understanding of the definition and focus of e-government;

OPPORTUNITIES NORWAY

- E-government strategy focused on promoting

ICT use and awareness among citizens;

- High level of Internet penetration and usage;

- High level of citizens' awareness of egovernment means less effort and resources need to be spent on promoting e-government, rather, these efforts can be focused on implementation;

- Opportunity to learn (and replicate best practice) from other leading e-government implementers;

\section{THREATS}

NORWAY

- Varying levels of perception at LG level of the importance of aligning national and local egovernment strategies;

- Local level e-government lagging behind other European nations;

- Citizens’ privacy and data protection seen as low important areas for e-government;

- More technology and less process and organisational change focused imblementation:

Figure 4: A SWOT Analysis of the UK and Norway's E-government Initiatives

\section{CONCLUSION}

The aim for this paper was to compare Norway's and the UK's ICT strategy in e-government implementation in local councils at a high level with a view of highlighting good practice strategies and implementation scenarios. The research method utilised a survey questionnaire to obtain this information from a local council perspective and the focus has been upon e-government definition; strategy; challenges; awareness; and organisational change. 
This research has reemphasised that strong leadership and commitment at central government level is a highly important component in e-government implementation. Obvious conditions such as a strong vision and a clear aim supported by transparent objectives and focus are also important for egovernment success. Another aspect that was clearly demonstrated in this research is the alignment of strategy between central government and local councils. In this context, a common understanding of the aim and definition of e-government across different local councils is important and needs to be supported with implementation plans that complemented central government strategy. While the UK has managed to maintain its e-government focus, Norway started well, lost momentum, but are now back up on the e-government rankings due to renewed motivation and a refocused strategy. Moreover, from a citizens' perspective, the level of awareness was seen to be higher in Norway when compared to the UK. E-government awareness is lacking in the UK and is worrying from a national perspective as it confirms that good strategies, plans and implementation projects will be meaningless if not backed up with appropriate marketing strategies to raise e-government awareness levels among citizens.

From a planning perspective, it is inappropriate to draw any conclusions regarding overall egovernment strategy in the UK and Norway given the limitations of this research as the empirical findings only represents the views of individuals in 12 UK and 16 Norwegian councils. Nonetheless, it can be argued that although Norway's e-government strategy is less comprehensive than the UK, their incremental approach to planning has worked well whereby the country has focused on a few themes/services at a time with decisions being made on a one-by-one basis (Earl, 1993) to implement and promote local e-government services.

Although from a strategy and implementation perspective e-government will differ from one country to another due to culture, social and economic settings and political environment, future research can nonetheless attempt to identify good practice for e-government implementation in common public administration processes. This could lead to the development of frameworks and guidelines for performing generic public administration and back office processes such as accountability arrangements and human resource management. This will not only prevent mistakes and duplication of resources, but also avoid reinventing the wheel in a more general e-government context.

\section{References}

Accenture (2001), eGovernment Leadership: Rhetoric vs. Reality - Closing the Gap; Accenture (2003), eGovernment Leadership: Realizing the Vision; Accenture (2004), eGovernment Leadership: High Performance, Maximum Value; Accenture (2005), Leadership in Customer Service: New Expectations, New Experiences http://www.accenture.com/

Botten, N. and Mcmanus, J. (1995), Competitive Strategies for Service Organisations, Macmillan Press, UK.

Bordens, K.S. and Abbott, B.B. (2001), Research Design and Methods: A Process Approach, McGraw-Hill, US.

Boulton, D. and Hammersley, M. (1996), Analysis of Unstructured Data, in Sapsford, R. and Jupp, V. ed. (1996), Data Collection and Analysis, The Open University, UK, pp. 281-297.

Cabinet Office (1999) Modernising Government, HMSO, London, UK.

Cabinet Office (2000) e-Government - Electronic Government services for the $21^{\text {st }}$ Century, Performance and Innovation Unit, HMSO, London, UK.

Chadwick, A. and May, C. (2003), Interactions between States and Citizens in the Age of the Internet: "e-Government" in the United States, Britain, and the European Union, Governance: An International Journal of Policy, Administration, and Institutions, 16(2), p271.

Cornford, T. and Smithson, T. (1996),Project Research in Information Systems: a Student's Guide, McMillan Press, London 
Creswell, J. W. (2003), Research Design: Qualitative, Quantitative and Mixed Methods Approaches, Sage, USA

Cuddy, Ian (2003) “New Moves for European eGovernment” Available at: http://www.egovmonitor.com/

Davison, R.M, Wagner, C, Ma, L.C.K. (2005), From government to e-government: a transition model”, Information Technology and People, 18 (3), pp.280-299

Deitel, H.M., Deitel,P.J.and Steinbuhler,K.(2001), e-Business and e-Commerce for Managers, Prentice Hall, NY

Denscombe, M. (2003), The Good Research Guide: for Small-scale Social Research Projects, OU, Press, UK

Earl, M.J.(1993), Experiences in Strategic Information Systems Planning, MIS Quarterly,17(1),pp1-24

Europe's Information Society (2004) “About eGovernment”, http://europa.eu.int/information_society/

Galliers, R.D. (1991), Strategic Information Systems Planning: Myths, Reality and Guidelines for Successful Implementation, European Journal of Information Systems, 1(1), pp.55-63

Gorman, G. E. and Clayton, P. (2005) Qualitative Research for the Information Professional: A Practical Handbook, Facet Publishing, London

Graetz, F., Rimmer, M., Lawrence, A. and Smith, A. (2002), Managing Organisational Change, Singapore: Markono Print Media Pte Ltd

Harlambos, M. and Holborn, M (2004), Sociology: Themes and Perspectives, HarperCollins Publishers, London

Hazlett, S. and Hill, F. (2003), E-government: The Realities of Using IT to Transform the Public Sector, Managing Service Quality, 6, pp.445-452.

Heeks, R. (1999) Reinventing Government in the Informatoin Age, Routledge, London, UK.

Holmes, D. (2001), e.gov e-business strategies for government, Finland: WS Bookwell

Hunter, D. R. and Jupp, V. (2001), E-government Leadership: Rhetoric vs. Reality - Closing the Gap, http://www.accenture.com/

Hussey, J. and Hussey, R. (1997), Business Research: A Practical Guide for Undergraduate and Postgraduate Students, Palgrave, UK.

Information Service Division (2002) Research Report. E-Government: Strategies and Countries Studies, Available at: http://www.nlb.gov.sg/IS/ResearchReportSample.pdf

Jackson, S. E., Joshi, A and Erhardt, N. L. (2003), Recent Research on Team and Organizational Diversity: SWOT Analysis and Implications, Journal of Management, 29 (6), pp. 801-830

Johnson, G and Scholes, K (1999), Exploring Corporate Strategy, Prentice Hall, England.

Lillrank, P.(1995),The Transfer of Management Innovations from Japan, Organisation Studies, 16(6), p.971-989.

Lowery, L. M. (unknown), Developing a Successful E-Government Strategy, Available at: http://unpan1.un.org/intradoc/groups/public/documents/apcity/unpan000343.pdf.

McFarlan, F.W.(1971),Problems in Planning the Information System, Harvard Business Review, 42(2), pp.75-89

Minzberg, H. (1994), The Rise and Fall of Strategic Planning, Prentice Hall International, UK.

Myers, M. D. (1997), Qualitative Research in Information Systems, http://www.qual.auckland.ac.nz/

Myers, M.D. and Avison, D. (2002), An Introduction to Qualitative Research in Information Systems, in Mayers, M.D. and Avison, D. (2002), Qualitative Research in Information Systems: A Reader Great SAGE, UK

National Assembly for Wales (2002) Guidance to Local Authorities on Implementing e-Government

Statements, National Assembly for Wales, Cardiff, UK.

Navarra, D. D. and Cornford, T. (2003), A Policy Making View of E-Government Innovations in Public Governance, Proceedings of the Ninth Americas Conference on Information Systems, Tampa, Florida

Norwegian Ministry of Labour and Government Administration (2001), 24/7 Public Administration Strategy and Measures, Oslo: Ministry of Labour and Government Administration 
Norwegian Ministry of Labour and Government Administration (2003), Strategi for IKT i offentlig sector [ICT strategy in public sector], Available at http://www.dep.no/archive/aadvedlegg/01/04/AADIK044.pdf

Norwegian Ministry of Modernisation (2005), eNorge 2009 - det digitale spranget (eNorway 2009 the digital leap), Available at http://www.odin.dep.no/mod/norsk/tema/ITpolitikk/bn.html

Norwegian Ministry of Trade and Industry (2004), eNorway: Status Report 2004, Available at: http://odin.dep.no/filarkiv/216212/eNorway_Status_Report_2004_web.pdf

Office of the Deputy Prime Minister (2002), The National Strategy for Local e-Government, http://www.localegov.gov.uk/

Office of the Deputy Prime Minister (2003) One year on The National Strategy for Local EGovernment, http://www.localegov.gov.uk/images/National\%20Strategy\%20\%201\%20year\%20on_248.pdf

Office of the Deputy Prime Minister (2005) Two Years On: Realising the Benefits from our Investment in E-Government, The National Strategy for Local E-Government, http://www.localegov.gov.uk/

OECD (1997), Electronic Commerce: Opportunities and Challenges for Government, Science Technology Industry, France

Reffat, R.M. (2003), Developing a Successful E-Government, Working Paper, School of Architecture, Design Science and Planning, University of Sydney, Australia.

Reynolds, M.M. and Regio, M. (2001), E-Government as a Catalyst in the Information Age, Microsoft E-Government Initiatives, E-Government 2001, http://www.netcaucus.org/books/egov2001/pdf/EGovIntr.pdf

Sambamurthy, V., Zmud, R.W. and Byrd, T.A. (1994), The Comprehensiveness of IT Planning Processes: A Contingency Approach, Journal of Information Technology Management, 5(10, pp.110

Silcock, R. (2001), “What is e-Government?”, Parliamentary Affairs, 55, pp.88-101.

SOCITM (2006) Local Government Transformation and the Council Website, SOCITM, UK.

Stamoulis, D., Georgiadis, G.P. and Martakos, D. (2001), Revisiting Public Information Management for Effective E-Government Services, Information Management and Computer Security 9(4), pp.146-153

Synodinos, N. E. (2003), The "Art” of Questionnaire Construction: Some Important Considerations for Manufacturing Studies, Integrated Manufacturing Systems, 14(3), pp. 221-237.

Valentin, E. K. (2001), SWOT Analysis from a Resource Based View, Journal of Marketing: Theory and Practice, 9(2)

Wimmer, M. A. (2002). "A European perspective towards online one-stop government: the eGOV Project." Electronic Commerce Research and Applications (1), pp. 92-103

www.computerweekly.com, Will e-targets get in the way?, http://www.computerweekly.com/Article102336.htm

Walliman, N. (2001). Your Research Project, London, UK, Sage Publications

Waseda University (2006), Waseda University E-Government rankings, www.obi.giti.waseda.ac.jp/e gov/2nd rankings en.pdf

www.kable.com, Government Computing Magazine, date accessed: July 19, 2002 